\title{
Microscopic Investigation of the Use of Gallium Nitrate for Root Surface Treatment in Rat Teeth Submitted to Delayed Replantation
}

\author{
Graziela Garrido MORI ${ }^{1}$ \\ Ivaldo Gomes de MORAES ${ }^{2}$ \\ Roberto Brandão GARCIA ${ }^{2}$ \\ Lilian Cristina Baraldi BORRO ${ }^{3}$ \\ Bruno Rombaldi PURIFICAÇÃO ${ }^{3}$ \\ ${ }^{1}$ Department of Integrated Clinics, School of Dentistry of Adamantina, Adamantina, SP, Brazil \\ ${ }^{2}$ Department of Restorative Dentistry, Endodontics and Dental Materials, \\ School of Dentistry of Bauru, University of São Paulo, Bauru, SP, Brazil \\ ${ }^{3}$ School of Dentistry of Adamantina, Adamantina, SP, Brazil
}

\begin{abstract}
The aim of this study was to investigate the effect of gallium nitrate solution, an anti-resorption substance, when applied for root surface treatment in rat teeth submitted to delayed replantation, in order to inhibit the root resorption process and enhance repair. For such purpose, 20 maxillary right central incisors of rats were randomly assigned to 2 groups $(n=10)$. In group I, root surface was treated with $10^{-4} \mathrm{M}$ gallium nitrate solution for $20 \mathrm{~min}$, while in group II root surface was treated with $2 \%$ sodium fluoride for 20 min. All root canals were filled with a calcium hydroxide-based paste. At 15 and 60 days after replantation, the animals were killed and the specimens were processed in laboratory for light transmission microscopy. In both groups, there was mild occurrence of ankylosis and root resorption. The connective tissue formed at the periodontal ligament area was arranged parallel to the root in most specimens in both groups and presented signs of inflammation. In group I, there was periodontal pocket formation in all specimens at 60 days, revealing lack of repair. These findings contraindicate the use of gallium nitrate for root surface treatment of teeth submitted to late replantation.
\end{abstract}

Key Words: gallium nitrate, root resorption, tooth replantation, tooth avulsion.

\section{INTRODUCTION}

Accidents affecting the teeth are very common. Their consequences may range from small tooth fractures to complete displacement from the socket, characterizing tooth avulsion (1). Repair may occur after tooth replantation. However, dental ankylosis and root resorption are common events in most cases (1). Root surface and endodontic treatment attempt to improve the repair and reduce the occurrence/severity of ankylosis and root resorption (1).

The use of fluoride on root surface, in addition to strengthening its structure, with formation of fluorapatite, is toxic to the resorptive cells acting in the hard tissues
(1-4). The use of calcium hydroxide as an intracanal therapeutic agent may avoid or limit inflammatory resorption (5) due to its alkaline $\mathrm{pH}$ and bactericidal effect (6) and thus eliminate the local infection.

Even with different treatment possibilities, the incidence of root resorption is still high and the survival rate of affected teeth is 4-6 years on the average (7). Hence, the search for new substances that may inhibit or delay the effects of the root resorption is demanding.

Due to the similar morphology, enzymatic properties and function of the cells causing dentin, cement and bone resorption, the processes of root and bone resorption may be considered similar $(1,8)$. Thus, drugs or other substances that are able to inhibit bone resorption 
may also be effective for treating root resorption.

The effectiveness of gallium nitrate in inhibiting bone resorption has been extensively demonstrated (913). Gallium incorporates into bone tissue, participating in the formation of fluorapatite. Hence, the newly formed bone becomes more resistant to the action of clastic cells and the resorption process is inhibited (912). Gallium nitrate may act on the proton pump, present in the clastic membrane, genetic expression or protein synthesis, or even carbonic anhydrase present in those cells (13). Bockman et al. (11) have reported that low gallium nitrate doses are sufficient for its activity.

The purpose of this study was to evaluate the effect of gallium nitrate solution applied for root surface treatment in rat teeth submitted to delayed replantation.

\section{MATERIAL AND METHODS}

Twenty male Wistar rats (Rattus norvegicus, albinus) weighing approximately 250-300 g were used for this study after approval of the study design by the Animal Research and Ethics Committee of the School of Dentistry of Bauru, University of São Paulo; Process \#11/2004). The animals received a grained solid diet and water ad libitum.

For surgical interventions, the animals were anesthetized intramuscularly with a mixture of ketamine (Dopalen; Sespo Indústria e Comércio Ltda, Jacareí, SP, Brazil) and xylazine (Anasedan; Agribrands do Brasil Ltda, Jacareí, SP, Brazil) at a dose of $0.05 \mathrm{~mL} / 100$ $\mathrm{g}$ of body weight for each substance. Asepsis of the anterior portion of the maxilla was performed with 0.12\% chlorhexidine digluconate (Periogard; Pfizer Ltda, São Paulo, SP, Brazil). The maxillary right central incisor was extracted, simulating a case of tooth avulsion.

The extracted teeth were kept dry, fixed by the crown to a red wax plate for $30 \mathrm{~min}$. The dental papillae of the teeth was excised with a \#11 scalpel blade (Embramac Exportação e Importação, Ribeirão Preto, SP, Brasil) for root canal exposure. The pulp was extirpated via apical foramen with a slightly curved \#15 Flexofile(Dentsply/Maillefer, Ballaigues, Switzerland). Root canal instrumentation was completed using \# 20 and \#25 Flexofiles (Dentsply/Maillefer). The root canals were copiously irrigated with a $1 \%$ sodium hypochlorite(Probem Produtos Farmacêuticos e Odontológicos Ltda, Catanduva, SP, Brasil) using 30x4 gauge needle attached to a Luer Look syringe.
The teeth were randomly assigned to 2 groups $(n=10)$. In group I, the teeth were immersed in $20 \mathrm{~mL}$ of $10^{-4} \mathrm{M}$ gallium nitrate solution (Acros Organics, Pittsburg, PA, USA; CAS \# 13494-90-1) for $20 \mathrm{~min}$, while in group II the teeth were immersed in $20 \mathrm{~mL}$ of 2\% sodium fluoride solution ( $\mathrm{pH} 5.5$ ) (Pharmácia Specífica, Bauru, SP, Brazil) for 20 min. The sodium fluoride solution was obtained from a mixture of $0.1 \mathrm{M}$ phosphoric acid ( $\mathrm{pH} 2$ ) and 2\% sodium fluoride ( $\mathrm{pH} 8$ ).

The root canals were then irrigated with sterile saline and filled with EDTA(Odahcam Dentsply Indústria e Comércio LTDA, Petrópolis, RJ, Brazil) for 3 min, rinsed with sterile saline again, aspirated with a 30x4 gauge needle attached to a Luer Look syringe and dried with sterile absorbent paper points (Tanariman Industrial Ltda, Manacapuru, AM, Brazil). All canals were filled with a calcium hydroxide-based paste (S.S. White Artigos Dentários Ltda, Rio de Janeiro, RJ, Brazil).

Thereafter, each tooth was replanted in its respective socket. No retention was placed. The animals received a single dose of 20,000 IU of benzatine G penicillin via intramuscular injection.

Five animals of each group were killed 15 and 60 days after replantation by anesthetic overdose. The right side of the maxilla was separated from the left at the midline with a \#15 scalpel blade (Embramac Exportação e Importação). The maxilla was then cut nearby the third molar in order to remove the hemimaxilla containing the replanted tooth.

The specimens were fixed in $10 \%$ buffered formalin for 7 days, decalcified in 4.13\% EDTA ( $\mathrm{pH} 7$ ), processed and embedded in paraffin to obtain crosssections of the cervical, middle and apical root thirds. Five-micrometer-thick slices were cut at each $100 \mu \mathrm{m}$ with a microtome, totaling 20 sections per specimen, which were stained with hematoxylin-eosin.

For microscopic analysis, the following parameters were evaluated: integrity of tooth structure, presence of cementum, characteristics of the connective tissue filling the periodontal space, occurrence of ankylosis and inflammatory or replacement resorption.

\section{RESULTS}

\section{Group I (Gallium Nitrate)}

At 15 days, the formation of a dense connective tissue parallel to the root surface was observed. Chronic 
inflammatory cells and some areas of blood clot were observed within this tissue. In some specimens, there was formation of periodontal pocket. Cementum was present in almost all specimens, except for areas of inflammatory resorption lacunae. Ankylosis was observed at a low rate.

At 60 days, the connective tissue filling the periodontal space exhibited few collagen fibers, several acute inflammatory cells and was arranged parallel to the root surface. All specimens presented periodontal pockets (Fig 1). Few inflammatory and replacement resorption lacunae were observed. Cementum was absent only at these scarce areas of root resorption. Ankylosis was observed at a low rate.

\section{Group II (Sodium Fluoride)}

At 15 days, a dense connective tissue parallel or perpendicular to the root surface was observed. The presence of connective tissue similar to the periodontal ligament (perpendicular) decreased with time, being completely absent at the later study period (Fig. 2). Cementum was present almost on the entire root surface. Some specimens exhibited small areas of inflammatory resorption. Ankylosis was present.

At 60 days, there was a remarkable amount of dense connective tissue with few inflammatory cells parallel to root surface. The number of inflammatory

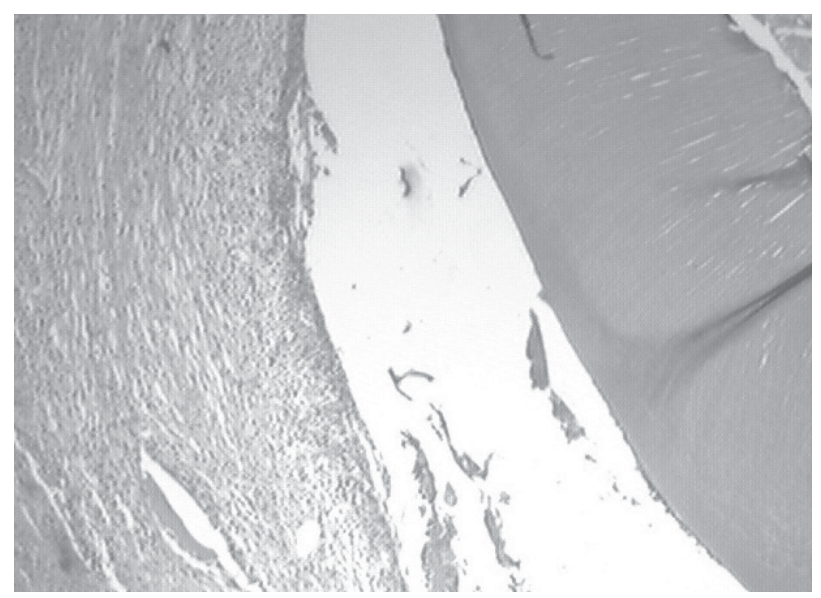

Figure 1. Group I (60 days). Connective tissue parallel to the root and presence of inflammatory cells. Note the presence of periodontal pocket and absence of resorption lacunae, with integrity of the cementum layer (Original magnification $\times 157.5$ ). resorption lacunae increased (Fig. 2) and replacement resorption was noticed in some areas. Cementum was absent only at the resorbed areas. Ankylosis was present.

\section{DISCUSSION}

Root resorption rate was small in both groups, which shows the capacity of sodium fluoride (1-4) and gallium nitrate (9-13) to act limiting the progression of the resorption process. Both substances are incorporated onto the mineralized surface, impairing the activity of the clastic cells and also acting directly on the osteoclasts.

Root surface analysis showed a direct relationship between the presence of root resorption lacunae and the absence of the cementum layer. This may suggest that both substances used for root surface treatment did not remove the cementum, which was absent only at the areas where root was not successfully inhibited.

The incidence of ankylosis in this study was low at both study periods. The presence of akylosed areas may be explained by the loss of epithelial rests of Malassez during tooth avulsion, as these structures have the role of maintaining the periodontal ligament space (14). The low incidence of ankylosis may be related with the small number of replacement resorption lacunae, which are consequence of ankylosis $(1,5,8)$.

The presence of connective tissue similar to

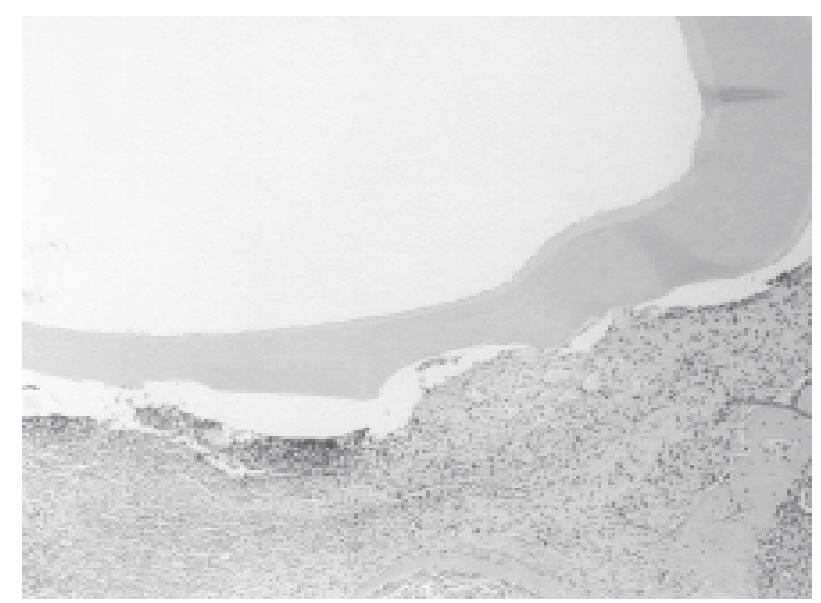

Figure 2. Group II (60 days). Connective tissue parallel to the root surface and presence of inflammatory cells. Note the existence of small areas of inflammatory root resorption (Original magnification $\times 63$ ). 
periodontal ligament was not observed at 60 days in group II (sodium fluoride); on the other hand, at the earlier period (15 days), this tissue was present in a considerable amount. This result might be better explained by the overlaying periodontal ligament fibers remaining on the alveolar wall when the tooth is replanted, rather than by new tissue formation (15-17). This periodontal ligament was replaced over time by a newly formed connective tissue, parallel to root surface.

Group I did not exhibit connective tissue similar to periodontal ligament, but showed a remarkable amount of connective tissue parallel to the root surface. At 60 days, periodontal pockets were evident, which suggests absence of repair in these areas. The lack of studies demonstrating participation of gallium nitrate solution in the repair of periodontal space impairs the discussion on a theory for the mechanism of action of these drugs in the healing process of replanted teeth. However, it may be suggested that the action of gallium nitrate on the root surface was irritating for the adjacent tissues, being effective only to limit the root resorption. Perhaps, the action of gallium nitrate might have been more valuable if it had been used as a root canal dressing.

Therefore, although the gallium nitrate solution allowed limitation of root resorption similar to that provided by sodium fluoride, the complete absence of repair in specimens of the gallium nitrate group contraindicates its uses for root surface treatment of teeth submitted to delayed replantation.

\section{RESUMO}

Este trabalho teve como objetivo testar o efeito da solução de nitrato de gálio, uma substância anti-reabsortiva, quando usada no tratamento da superfície radicular de dentes reimplantados tardiamente, com o intuito de inibir o processo de reabsorção radicular e facilitar o reparo. Para isso, foram utilizados 20 incisivos centrais superiores direitos de ratos, divididos em 2 grupos $(n=10)$. No grupo I, a superfície radicular foi tratada com solução de nitrato de gálio a $10^{-4} \mathrm{M}$ por 20 min e no grupo II com fluoreto de sódio a $2 \%$ por 20 min. Todos os canais foram preenchidos com pasta de hidróxido de cálcio. Após 15 e 60 dias do reimplante, os animais foram mortos e as peças obtidas, processadas em laboratório para análise em microscópio de transmissão de luz. Em ambos os grupos, houve pequena ocorrência de anquilose e reabsorção radicular. O tecido conjuntivo formado no espaço do ligamento periodontal disposto paralelamente à raiz, na maioria dos espécimes dos dois grupos, mostrou-se inflamado e com algumas áreas de necrose. No grupo I, houve a formação de bolsa periodontal em todos os espécimes aos 60 dias, indicando a ausência de reparo. Estes achados desaconselham o uso do nitrato de gálio para o tratamento de superfície de dentes reimplantados tardiamente.

\section{REFERENCES}

1. Andreasen JO, Andreasen FM. Textbook and colour atlas of traumatic injuries to the teeth. 4th ed. Copenhagen: Blackwell Munksgaard; 2007.

2. Bjorvatin K, Massler M. Effect of fluorides on root resorption in replanted rat molars. Acta Odont Scand 1971;29:1729.

3. Coccia CT. A clinical investigation of root resorption rates in reimplanted young permanent incisors: a five-year study. J Endodon 1980;6:413-420.

4. Shulman LB, Gedalia I, Feingold RM. Fluoride concentration in root surfaces and alveolar bone of fluoride-immersed monkey incisors three weeks after replantation. J Dent Res 1973; 52:1314-1316.

5. Tronstad L. Root resorption-etiology, terminology and clinical manifestations. Endod Dent Traumat 1988;4:241-252.

6. Siqueira Jr JF, Lopes HP. Mechanisms of antimicrobial activity calcium hydroxide: a critical review. Int Endod J 1999; 32:361-369.

7. Pavek DI, Radtke PK. Postreplantation management of avulsed teeth: an endodontic literature review. Gen Dent 2000;48:176-181.

8. Ne RF, Witherspoon DE, Gutmann JI. Tooth resorption. Quintessence Int 1999;30:9-25.

9. Bockman RS, Boskey AL, Blumenthal NC, Alcock NW, Warrell RP Jr. Gallium increases bone calcium and crystallite perfection of hydroxiapatite. Calcif Tissue Int 1986;39:376381 .

10. Cournot-Witmer G, Bourdeau A, Lieberherr M, Thil CL, Plachot JJ, Enault G, et al. Bone modeling in gallium nitratetreated rats. Calcif Tissue Int 1987;40:270-275.

11. Bockman RS, Wilhelm F, Siris E, Singer F, Chausmer A, Bitton R, et al. A multicenter trial of low dose gallium nitrate in patients with advances Paget's disease of bone. J Clin Endocrinol Metab 1995;80:595-602.

12. Warrell RP Jr. Gallium nitrate for the treatment of bone metastases. Cancer 1997;80:1680-1685.

13. Bernstein LR. Mechanisms of therapeutic activity for gallium. Pharmacol Rev 1998;50:665-682.

14. Löe H, Waerhaug J. Experimental replantation of teeth in dogs and monkeys. Arch oral Biol 1961;3:176-184.

15. Mori GG, Garcia RB. Microscopic study of the effect of root surface treatment with acetazolamida in avulsed and re-implanted rat teeth. J App Oral Sci 2002;10:180-185.

16. Mori GG, Garcia RB, Moraes IG. Morphometric and microscopic evaluation of the effect of solution of acetazolamide as an intracanal therapeutic agent in rat teeth submitted to late replantation. Dent Traumatol 2006;22:36-40.

17. Mori GG, Garcia RB, Moraes IG, Bramante CM, Bernardineli N. Morphometric and microscopic evaluation of the effect of solution of alendronate as a root canal dressing in rat teeth submitted to late replantation. Dent Traumatol 2007;23:218221. 